\title{
Adherence to Legal Culture as a Component of the Regional Industrial Enterprises' Corporate Innovation Management while Ensuring their Sustainable Development
}

Yuliia Klius $^{1}$, Liubov Kotova², Yuliia Ivchuk ${ }^{3}$, Oleh Skupinskyi ${ }^{4}$

\begin{abstract}
The article is to determine the role of the compliance culture as a part of the regional industrial enterprises' corporate innovation management while ensuring their sustainable development. Any enterprise, operating in a market economy, aims to maximize profits as its main internal goal. Effective innovative development is an objective necessity for sustainable economic growth. The main goal of the innovative activity of enterprises or organizations can be designated as obtaining a certain number of innovations in the form of new products, technologies, raw materials, methods of organization and management with certain features. The formation of new and efficient innovation management systems by means of straight-line management is of great importance for industrial enterprise's effective development management. The creation of new and efficient systems of management of innovation activity to direct it into an effective path is greatly important for effective development management of the industrial enterprise. Therefore, the innovation management corporate system creation and the study of its role in the effective development of the enterprise is extremely relevant.
\end{abstract}

Keywords: legal culture, innovative activities, industrial enterprises, sustainable development

\section{Introduction}

In today's environment, innovative entrepreneurship has very specific features: a combination of legal nihilism and legality demand, innovation and routine, high requirements for a partner and the non-obligation to fulfill contracts, a symbiosis of different cultures and values. However, despite this inconsistency, Ukrainian innovative entrepreneurship is one of the few productive forces that accelerates the processes of transformation and positive development of the national economy, and forms a trend for sustainable development in the future. Therefore, it is extremely important to improve the institutional framework for the Ukrainian economy development, including the legal framework, which is the main condition for its stabilization. According to the representatives of the institutional economy, revolutionary changes in the productive 
forces are associated not only with scientific discoveries, but also with changes in laws and public policies. Noting the controversial nature of the innovative infrastructure development in Ukraine, it is important to emphasize a new public administration and legislative structure gradual formation in recent years that ensure the functioning of the innovation sphere in market conditions. The introduction of scientific and innovative projects competitive financing through a system of various funds, including venture funds, the provision of certain tax benefits for research and development, and reform in the field of intellectual property rights protection can be noted as the most important institutional innovations. However, the carried out changes and reforms were contradictory and limited, legislative and enforcement issues stayed imperfect or incomplete (as in the case of The Tax Code, for example).

\section{The genesis of legal culture in corporate governance of innovation in industrial enterprises in the region}

Not a single economic phenomenon arises spontaneously. It has its own background. The corporation has its predecessors; based on their experience this economic-legal structure was formed. The final model of the corporation was formed as a result of the initial adaptation of the existing structures to new relationships, later their struggle, that led to the creation of the corporation. That is why some signs of a corporation in one form or another can be found at various stages of the human civilization development (Bezus, 2016).

It can be considered that the history of corporate relations began with Ancient Rome the first state where their origin and development occurred. The growth of the territory of the Roman state, the conquest of such states as Corsica, Sardinia, Greece (neighboring territories), the development of trade with other states, and the expansion of the range of activities of economic entities led to the development of Roman law. At that time, Rome was a society with a prosperous economy, a high culture of economic relations and a reliable protection of citizens' property. Revenues from overseas trade were distributed proportionally between the owners of the ship and cargo and all entrepreneurs who took part in the business with their loans. The Romans considered it a general economic rule that it was better to participate in small shares in several "speculations" than to do independent operations. There are known instances when an entire city merged into a society interested in various financial enterprises run by several prominent persons. As a result, even people with worthless financial savings were involved in buying taxes, leasing public land. Considering that a large number of people were involved in such financial affairs, Roman society was aware of a major economic collapse. It was in the Roman state that the first professional and religious unions were created, which, in our opinion, are the prototype of a corporate organization (corporate organizations, prototypes of a modern legal entity - universitas corpus, as well as a publicans society (cocietates vectigularium publicanorium), which were mixed form cocietas and universitas, that was the first real prototype of the corporation. In ancient Rome, as well as in Byzantium, which preserved Roman legal traditions, the principles of limited liability were legislated, and profit and loss were distributed in proportion to contributions).

Much later, due to the development of trade, trade guilds began to appear, uniting 
merchants in one or more of these types of activities, in which funds were accumulated, which made it possible to achieve global economic goals. Membership in the guild provided for joint responsibility, which was based on uniform conditions for joint activities. Such guilds formed the customs of doing business, a set of explicit and implicit rules of internal relationships. Three main examples can be distinguished, based on which the development of the legal foundations of corporatism took place, which, in turn, is associated with guilds.

On the Russian Empire territory, the first joint-stock companies, that is, legal structures close to the institute "joint-stock company" in its modern sense, arose at the beginning of the XIX century. The very concept of a "joint-stock company" and the most important legal principle on which it is based (lack of shareholders' liability for the company's debts and risk only by the value of their shares) were known to Russian reality from the 18th century. Only at the beginning of the 19th century the first legislative acts appear governing similar relationships. In 1991, a number of basic laws were adopted regarding the legal regulation of entrepreneurial activity: the Laws of Ukraine "On Entrepreneurship", "Property", "On Securities and Stock Exchange". The adoption of these regulations laid the legal foundation for the development of market relations in Ukraine; for the first time, the participants in such relations were identified: that were entrepreneurs of various legal forms, including associations (Dmitrichenko, 2010).

Adoption of regulations (Laws of Ukraine "On Entrepreneurship", "Property", "On Enterprises in Ukraine", "On Securities and Stock Exchange") laid the legal foundation for the development of market relations in Ukraine, for the first time identified participants in such relations - entrepreneurs of different organizational and legal form, including corporations (Garafonova, 2015).

The legal status of business associations as corporate subjects of entrepreneurial activity was fixed in a special legislation adopted in 1991. It is about the Law of Ukraine "On Business Associations" dated 09/19/1991. It covers the creation, functioning and termination of business associations (Ganzyuk, 2016). In this regulation, there are five forms of companies: joint stock company, limited liability company; with additional responsibility; complete and limited. To date, this Law remains one of the main sources in the field of corporate law.

It should be noted that, despite the extensive legal framework governing the order of innovation activity of industrial enterprises, some of them are not regulated by the law. First of all, it has to do with the holding companies. An analysis of a number of legislative and other normative acts showed that the only holdings created in the process of corporatization and privatization are considered, and is regulated by the Decree of the President of Ukraine "On holding companies established in the process of corporatization and privatization” dated 11 May 1994p. (Garafonova, 2015).

In addition to privatization processes, the corporatization processes took place in Ukraine between 1995 and 1998. The peculiarity of the integrated corporate structures (holdings, concerns) in Ukraine was not only their rapid growth, that was significantly outpaced the formation of the legislation base and culture of corporate governance, but also the substitution of the very meaning of their creation, especially when it was about the corporation that were created during the privatization process (Ganzyuk, 2016).

The most important problem for the Ukrainian economy today is the emergence of the 
corporate sector, as most large enterprises that have undergone privatization have received a significant degree of freedom of financial and economic activity in the legal form of joint-stock companies. The most important problem for the Ukrainian economy today is the emergence of the corporate sector, as most large enterprises that have undergone privatization have received a significant degree of financial and economic freedom in the legal form of joint-stock companies (Dmitrichenko, 2010).

The transition of the Ukrainian economy to a market management system has led to the emergence of many new organizational and legal forms of economic activity (Garafonova, 2015). Due to the state property privatization, state-owned enterprises turned into joint-stock companies and, on the basis of economic feasibility, created new technological chains and merged into corporate structures (Garafonova, 2015).

Keeping its essence (principles of property relations and separation of responsibilities), the dynamics of the development of organizational and legal forms of managing in Ukraine is characterized by the relative speed of transition and development of the legal, financial, information space for their implementation.

Thus, such main provisions, as an effective regulatory framework and the provision of necessary resources, the main of which are financial security, determine the development of innovation. We also note that for the development of innovative activities of economic entities, it is necessary to create an innovative infrastructure that meets modern market requirements. It allows to activate potential investors, and also helps to reduce the existing investment risk. However, appropriate conditions must be created for the public authorities.

\section{Legal support for sustainable development of industrial enterprises of the region in their implementation of innovative activities}

The more and the greater the innovation is the more resources it requires to develop and distribute, the more participants, and the bigger the risk and weight of failure are (Kuznecova, 2006). Competitions of innovators (and, above all, market competition) in pursuit of an "innovative carrot" - an innovative super-profit, political or social success, recognition of the creative contribution of a scientist, writer, artist, musician - motivates those who desire success for innovation, despite the risks. Many of them fail, but those who have made successful innovations offer new perspectives in their chosen field.

An important player in the innovative field, which performs selection of current and necessary innovative projects, is the state (Kuznecova, 2006). It defines legislative rules of the game on this field, which is distinguished by significant specificity in comparison with current activity, forms a favourable (or unfavourable - as in modern Ukraine) innovative climate, ensures observance of established norms and rules of innovative activity. However, this is not limited to the role of the state. It should carry out a strategically innovative function: To support basic technological and economic innovations, providing them with initial impulse; to produce at their own expense innovations in the non-market sphere of the economy, and above all in defence, health, basic science, education, culture; to carry out innovations in the state-legal sphere, etc. In this regard, civil servants are the same innovators as entrepreneurs and investors. If the 
state apparatus is conservative, does not support innovations and, moreover, prevents them, pursues an anti-innovation policy, then the country is doomed to an innovation crisis, lagging behind the general rhythm of transformation.

During the period of renewal and change of social systems, the social law of fluctuations of totalitarianism and freedom, justified by Pitirim Sorokin, is being implemented. It provides that in crises, "the scale and severity of government regulation invariably increase, and the economy of society, the political regime, way of life and ideology are experiencing a totalitarian transformation; and, the more severe the crisis, the greater this transformation. On the contrary, every time a severe crisis in society diminishes, the scope and severity of government regulation decline, and economic, political, ideological, and cultural systems are converted to peaceful, untotalitarian, less regulated, and freer images of life ..." (Nikolaev, 2001).

In other words, the scale of innovation activity of the state, its role and responsibility in selection and support of the most effective basic innovations in various spheres of society in crisis transitional situations significantly increase (Kuznecova, 2006). In this situation, it is advisable for industrial enterprises to base their development strategy on the principles of sustainable development, which ensures:

organizational, economic, financial stability of the enterprise to risks, crisis, loss of its competitiveness;

necessary adjustment of the enterprise development strategy taking into account changes in the external environment.

The reasons for the insufficiently effective development of innovation are primarily the lack of system integration and interaction of elements of the research environment. The reasons for this lie primarily in the weakness of the legislative regulatory framework for the scientific and innovative sphere. The country still lacks a law regulating the requirements for innovation and the conditions for its development. Existing legislation and laws require changes that enhance the incentive nature of the state regulators of innovation. The legal framework in the field of scientific, technical and innovation activity is the most important element of the innovation system. In the future, work is to be done on regional intellectual property legislation. The unresolved problems of copyright for the results of research and a number of others is a brake for the use of scientific ideas in practice, one of the reasons for the "shadow export" of Ukrainian technologies and promising developments abroad and low patent activity.

The formation of legal awareness is to promote the development of civic consciousness, humanization of legal thinking, voluntary performance of legal rules based on strong conviction and high legal culture. Legal regulation effectiveness of social processes and rule of law development depend on raising the level of legal culture and citizens' awareness (Arsentieva, 2017).

The shortcomings of the existing legislation of the industrial enterprises operating in the region include the discrepancy of accounting information and forms of financial activity to international requirements and standards provided by issuers of securities; the lack of a perfect system of stock market control that would prevent transactions with securities using insider information. This would prevent the manipulation of prices on the stock market, protect domestic stock market participants from competition of non-residents, stop transactions with securities and prevent securities from accessing stock exchanges 
or in the over-the-counter trading system in the event of a violation of securities legislation. The absence of a developed national stock exchange and clearing system on securities as well as the imperfection of the tax system for securities transactions makes it extremely difficult to develop the stock market in Ukraine. It should be noted that state regulation in the secondary stock market plays a very significant role, especially now, during the formation of this market, but the state of secondary market regulation in our time can be considered unsatisfactory.

Not to forget, that when creating a legal framework for determining the rights and responsibilities of the parties and regulating their relationship, each party is able to plan and implement its strategy, and through it to assess the behavior of other parties. Corporate legislation provides the basis for cooperation of all participants in corporate activities.

\section{Legal culture as a component of innovative culture in the corporate system of industrial enterprises' innovation management in the region}

It is important to consider that innovation potential is formed within the industrial enterprise under the influence of corporate innovation management, reflecting the holistic orientation of employees, fixed in motivation, knowledge, skills, images and norms of behavior. This power will be called an innovative culture, as it is designed to provide the formation of a receptive environment for innovation in the enterprise. Innovative culture provides sensitivity of economic entities and people to some new ideas, their attempts to maintain and introduce innovations in all spheres of activity and life. The formation of an innovative culture is connected primarily with the development of creative abilities and the realization of the creative potential of the person - its subject (French, 2002). At the same time, there are many other factors and conditions, the accounting and active use of which can significantly contribute to the effectiveness of innovation (French, 2002).

The range of manifestation of an innovative culture is unlimited, and the starting point is the creation of conditions for the effective use of innovative potential (individuals, enterprises). Innovative culture as a special form of human culture implies a close relationship with its other forms, primarily with legal, managerial, entrepreneurial, corporate (Klius, 2017). An innovative culture can have a significant impact on the entire culture of people's productive relationships and their professional activities.

Thus, management of innovation potential, innovative infrastructure and innovative culture forms a system - corporate system of innovation management of industrial enterprises of the region.

The significance of the corporate system of innovation management is growing because of not only the quantitative expansion of the participants of the innovative market economic entities and specialists, but also because of the complexity of the tasks they solve - scientific, technical, economic, legal protection of intellectual property. Consequently, the role of methods of spreading innovations, instruments of technical and economic expertise also increases.

The authors have formed the structure of the corporate innovation management system (Fig. 1), through which it is proposed to carry out the process of formation of the 
corporate innovation management system in the industrial enterprises of the region (Klius, 2017).

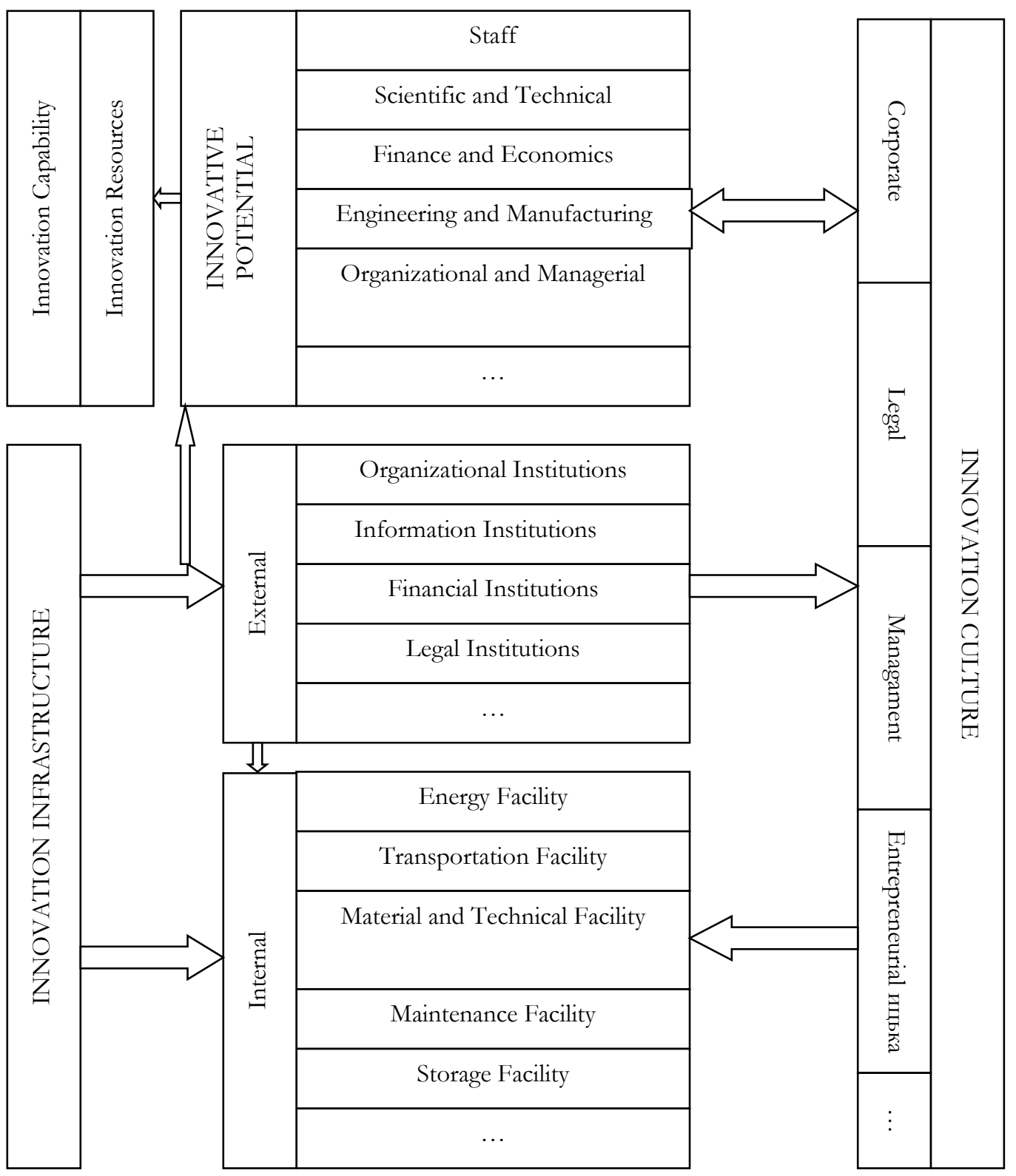

Fig. 1. The structure of the corporate innovation management system [author's development]

The structure is formed according to the modular principle and consists of three blocks, allowing to estimate all components of the corporate system of innovation management of the enterprise, namely innovative opportunities and innovative resources (innovative potential), innovative infrastructure and innovative culture. 
The structure allows the inclusion of subunits in any of the blocks for a more detailed study of the characteristics of the corporate innovation management system, for example: external innovation infrastructure (legal institutions, organizational institutions, financial institutions and others); internal innovation infrastructure.

The optimization of the external innovative infrastructure takes place at the level of state and regional executive authorities through the legal interaction of statistical bodies, technoparks, research institutes, as well as financial institutions (banks, exchanges, insurance, auditing companies) and information bodies and services. State efforts to stimulate external innovation infrastructure should focus on promoting the development of the business and information services market for innovation - financial and legal consulting, patent protection.

An integral part of the corporate innovation management system, which ensures people's susceptibility to new ideas, their readiness and ability to support and implement innovations, is an innovative culture. Innovation culture is based on corporate culture, legal culture, managerial and entrepreneurial culture. The contents of the components of the innovative culture are given in the table 1.

Table 1. The Main Components of the Innovative Culture of the Industrial Enterprise (Knyazevich, 2016)

\begin{tabular}{|l|l|}
\hline \multicolumn{1}{|c|}{$\begin{array}{l}\text { Components } \\
\text { Culture }\end{array}$} & $\begin{array}{l}\text { Content } \\
\text { tresented as objective (buildings, structures, equipment, workplace, technology, } \\
\text { (values, beliefs, norms of behaviour, mythology). }\end{array}$ \\
\hline Legal Culture & $\begin{array}{l}\text { On the one hand, the production, storage and transfer of legal values, } \\
\text { information, traditions that promote the legitimate social active behaviour of } \\
\text { people are ensured in accordance with the achieved level of legal consciousness } \\
\text { through a special social mechanism. On the other hand, as an expression of the } \\
\text { state-legal experience of specific social communities and individuals in material } \\
\text { and spiritual processes, products of life, in skills and values that affect their } \\
\text { legally significant behaviour. }\end{array}$ \\
\hline $\begin{array}{l}\text { Management } \\
\text { Culture }\end{array}$ & $\begin{array}{l}\text { Provides control over the results, high percentage of implementation of the } \\
\text { decisions taken, ability of the manager to control the motivation of employees of } \\
\text { the enterprise (emphasis on non-material incentives - creation of a favourable } \\
\text { psychological climate, consideration of individual qualities of employees, creation } \\
\text { of an atmosphere of creative self-realization). }\end{array}$ \\
\hline $\begin{array}{l}\text { Entrepreneurial } \\
\text { Culture }\end{array}$ & $\begin{array}{l}\text { It is a system of values, meanings, symbols, knowledge, traditions that provide } \\
\text { the motivation and regulation of entrepreneurial activity that determine the form } \\
\text { of its implementation, as well as its perception by society. }\end{array}$ \\
\hline
\end{tabular}

The essence of the legal culture is directly conditioned by the nature of law as an integrative regulator of the rule of law, which expresses general political justice in the system of principles and norms, accurately determine the circle of subjects of law, their legal rights, duties and guarantees to ensure social progress.

The legal culture of society is one of the most important components of the general culture, as it largely determines the modern law-abiding citizen appearance. The presence of this or that level of legal culture allows us to judge the state of law and order in the state as a whole, as well as the conduct of economic activities. This institute is necessary 
for all sections of the population, regardless of their type of activity or affiliation with certain sections of the population. Unfortunately, at present the legal culture of Ukrainian society is still not at an acceptable height for the modern state (Buzko, 2002). This statement can also be attributed to the level of legal culture of the industrial enterprises. It should be noted that in our time, a significant part of the subjects of entrepreneurial activity know poorly the legislation that fixes and regulates this type of activity. They are poorly in possession of legal mechanisms for the protection of their rights and legitimate interests; not oriented or not very well oriented in the ways carrying out of economic activity lawfully. The low level of legal culture of part of the business community leads not only to the inability of the latter to conduct its activities efficiently and effectively, but also indulges in the commission of various types of offenses, including crimes, both by representatives of businessmen themselves, and by consumers and others. And today there are often unscrupulous entrepreneurs who are ready to conduct their business in every way, including not entirely legal and are ready to take every action to obtain additional profit.

Meanwhile, such a situation can become a significant obstacle to the formation of a radically updated, innovative business model in our country. The low level of legal awareness and legal culture of a number of domestic entrepreneurs creates obstacles for the development of innovative branches of the economy and adds features to the image of the state in the international arena. The lack of legal culture and legal awareness, among other things, leads to the fact that many entrepreneurs are aimed at instant, rapid enrichment and do not want to invest their funds in long-term projects. All the abovementioned circumstances dictate the urgent need for qualitative improvement of the level of national businessmen's legal culture.

One of the directions of enhancing the legal culture of entrepreneurs could be the development of legal education in Ukraine among all social groups, including business representatives (Bezus, 2016). Legal education for businessmen can take many different forms, ranging from the organization of special seminars and conferences on specific issues of business activities and ending with comprehensive professional training, retraining and advanced training.

Another way to increase the legal culture and legal consciousness of the subjects of entrepreneurial activity in order to develop a modern innovative model of the economy could be the creation in the society of a positive image of a law-abiding entrepreneur. It is necessary to develop a comprehensive program to create such an image, explain to entrepreneurs that doing business honestly and on the basis of legal norms is beneficial not only for the state, society and consumers, but also for the entrepreneur himself. Only under such conditions will the business in our country be aimed at constant development and improvement, and not at maximum profit-making in short time by any means possible. Social responsibility of business is an important component of the policy of the modern state.

\section{Conclusion}

The legal culture of entrepreneurs' acts as only one aspect of the implementation of business activities, however, this aspect is largely basic, determining for all the others. 
On how legitimate the business is, to a large extent depends on its content. In this connection, the solution of problems related to the implementation of this aspect should be put as one of the most important tasks of our state and society life. A significant increase in legal culture is possible only if to take the system approach to solving this problem. It is necessary to develop, on the one hand, strategic directions for enhancing the legal culture, and on the other hand, a logically coordinated, integral system of structures with their specific tasks, functions, and powers in line with these directions.

The main areas should include: a more rational use of the country's legal potential; creation of a coherent system of continuous training for all lawyers; creation of real favorable conditions for the development of legal science; improving legal education; reproduction of the earlier carried out legal comprehensive education of the country's population.

Thus, the creation and functioning of the industrial industry's innovative system as a complex of related institutions of legal, economic, scientific and technical nature will allow the industry to engage timely innovation activity in the sustainable development.

\section{References:}

Arsentieva O., etc. (2017) Some aspects of law education of pupils in conditions of forming of civil society: monograph. Transformations in Contemporary Society: Social Aspects. Monograph. pp.380.

Buzko I.P., Vartanova O.V., Golubchenko G.O.(2002), Strategic management of innovations and innovative activity of the enterprise: monograph. Lugansk: Vyd'vo SNU im. V.Dalya. (in Ukraine).

Bezus A. M., Shafranova K.V. (2016). Development of Small Business Enterprises in Ukraine. Visnyk Kyyivskoho natsionalnoho universytetu tekhnolohiyta dyzaynu. Ekonomichni nauky, vol. 3 (99), pp. $7-17$.

Bezus P. I., Bezus A. M. (2014), Factors influencing the formation and implementation of theenterprise's innovative strategy, Naukovyy visnyk. Seriya «Ekonomika», vol. 1, pp. 61-69.

Corporation in the system of social production: monograph (2010). L. I. Dmitrichenko, T. S. Chunihina, L. A. Dmitrichenko, A. N. Himchenko. Doneck : Shid. vid. dim, 184 p.

French D. A. (2002), The Role of the State and International Organizations in Reconciling Sustainable Development and Globalization. International Environmental Agreements: Politics, Law and Economics, 2,135-150. doi: 10.1023/A:1020912808651

Ganzyuk S. M. (2016), Dynamic monitoring of the investment climate in Ukraine. Molodij vchenij. Vol. 1(1), p. $43-47$

Garafonova O. I. (2015), The strategy of implementation of change: theoretical and methodical approaches to its definition. Strategiya ekonomichnogo rozvitku Ukrayini. vol. 37. pp. 63-72.

Gnilyanskaya L.Y. (2011), Modern problems of introduction of innovations and ways of their overcoming. Naukovyy visnyk NLTU Ukrayiny, vol. 1, no 3, pp. 32-39.

Klius Y. (2016), Managing the effective development of an industrial enterprise in the formation of a corporate innovation management system. Biznes-Inform. vol. 12 (467), p. 280-286.

Knyazevich A. O. (2015), The market of innovations in the structure of innovative infrastructure of the country. Marketing i menedzhment innovacij. vol. 3. pp. 129-139.

Khariv P. S. (2003), Innovative activity of the enterprise and economic evaluation of innovative processes]. Ternopil: Ekonomichna dumka. (in Ukraine).

Kuznecova I. S. (2006), Innovative systems: essence, structure and development problems. Internet-zhurnal «Innovaciyi v Kiyevi» [www.innovation.com.ua]. vol 1. pp. 12-15.

Mikitiuk P. P., Senov B. G. (2009), Innovatsiyna diyalnist: navch. posib. [Innovative activity: teaching manual], Kyiv, Tsentr navch. lit. (in Ukraine).

Nikolaev A. I. (2001) Innovative development and innovative culture. Nauka i naukoznanie. vol. 2. pp. 5465. 